Elemental Psychology and the Date of Semonides of Amorgos

Author(s): Thomas K. Hubbard

Source: The American Journal of Philology, Vol. 115, No. 2 (Summer, 1994), pp. 175-197

Published by: The Johns Hopkins University Press

Stable URL: http://www.jstor.org/stable/295298

Accessed: 28-05-2015 20:42 UTC

Your use of the JSTOR archive indicates your acceptance of the Terms \& Conditions of Use, available at http://www.jstor.org/page/ info/about/policies/terms.jsp

JSTOR is a not-for-profit service that helps scholars, researchers, and students discover, use, and build upon a wide range of content in a trusted digital archive. We use information technology and tools to increase productivity and facilitate new forms of scholarship. For more information about JSTOR, please contact support@jstor.org. 


\section{ELEMENTAL PSYCHOLOGY AND THE DATE OF SEMONIDES OF AMORGOS}

The date ascribed to the iambic poet Semonides of Amorgos has long been a matter of scholarly uncertainty. ${ }^{1}$ Ancient chronographic sources present us with a welter of confused and contradictory statements; for the most part, they associate him closely with Archilochus as a poet of the early seventh century, although one ambiguous testimonium may suggest a late sixth-century date. Modern literary historians seem to favor a date in the second half of the seventh century, although with no real evidence. ${ }^{2}$ After reexamining the chronographic sources, I wish to call attention to a passage in Semonides' poetry whose bearing on this question has hitherto been neglected. I argue that Semonides' depiction of the Earth-woman and Sea-woman (fr. 7.21-42 W) reflects a stage in the evolution of elemental theory quite inconceivable for the seventh century, but more consistent with the late sixth century. I then proceed to discuss some other aspects of Semonides' work which confirm this down-dating.

\section{CHRONOGRAPHIC EVIDENCE}

For the sake of the following discussion, I first quote in full the relevant testimonia:

I. Clement of Alexandria Strom. 1.21.131 (Dindorf): . . tòv 'A @xíno-

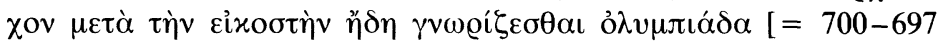

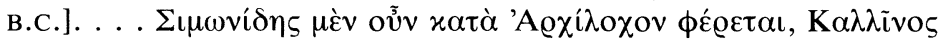

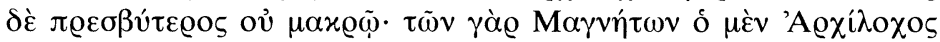

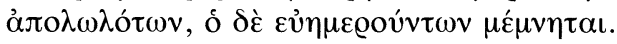

II. (A) Jerome Chron. OL. $29.1=664$ в.c. (p. 94e Helm): Archilochus et Simonides et Aristoxenus musicus inlustres habentur.

${ }^{1}$ For a review of scholarship on the question see Pellizer, "Sulla cronologia" 17-23.

${ }^{2}$ See Schmid and Stählin, Geschichte I.1 398; Campbell, Greek Lyric Poetry 184; Gerber, Euterpe 53; Easterling, "Semonides" 113. However, Lesky, History 114, seems to follow the chronographers in identifying him as "roughly contemporary with Archilochus." For criticism of the very tenuous grounds on which the late seventh-century date is maintained, see Pellizer, "Sulla cronologia" 20-22.

American Journal of Philology 115 (1994) 175-197 1994 by The Johns Hopkins University Press 
(B) Eusebius Chron. (Armenian version) AA $1351=665$ в.C. (p. 184 Karst): "Archilochus und Simonides wurden gekannt."

III. Cyril of Alexandria Contra Julianum 1.14 (Burguière and Evieux):

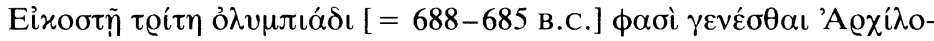

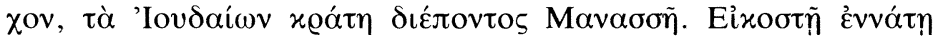

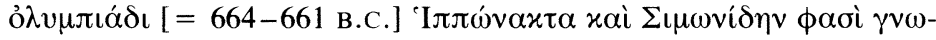

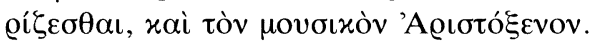

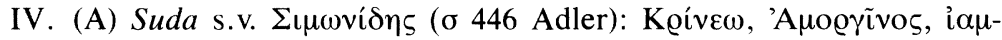

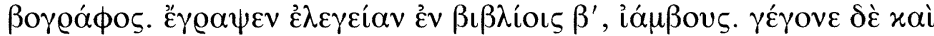

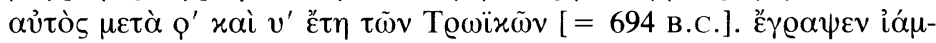

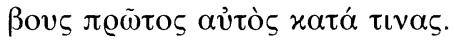

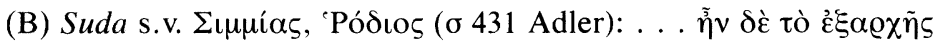

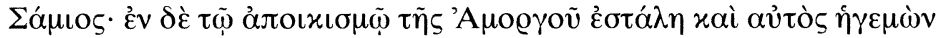

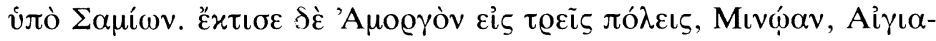

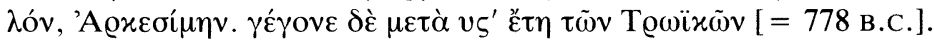

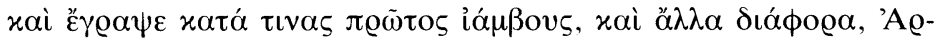
$\chi \alpha \iota \lambda_{o \gamma i ́} \alpha \nu \tau \varepsilon \tau \tilde{\omega} \nu \Sigma \alpha \mu i ́ \omega v$.

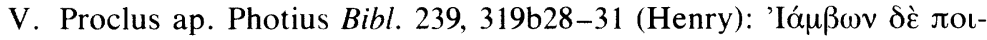

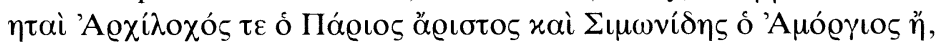

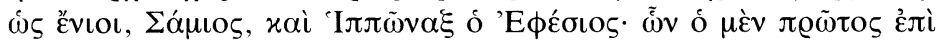

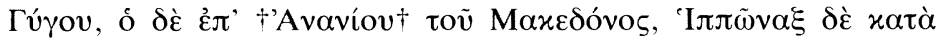
$\Delta \alpha \varrho \varepsilon i ̄ o v \eta \eta \mu \mu \alpha \zeta \varepsilon$.

The ancient chronographic tradition, particularly in regard to biographical dates of the archaic age, is a veritable morass of confusion, corruption, and conjectural synchronisms, often beset by the worst excesses of Alexandrian vita traditions. Nowhere is this more true than in regard to Semonides, whose very name was not even known correctly. ${ }^{3}$ The earlier the period, the less precise the information available to the chronographers and their Alexandrian sources, and the greater their tendency to conjecture dates based on comparison with the few historical figures or events whose dates could be determined. Any scholar who has worked very long with this material cannot help but develop considerable skepticism about its reliability and value for dates

${ }^{3}$ The only source to give the form "Semonides" is the late grammarian Choeroboscus, ap. Et. Magn. 713.17, who specifically distinguishes him from the lyric poet "Simonides." 
prior to the fifth century: ${ }^{4}$ the dates which the chronographers transmit for Homer and Hesiod are pure fantasy, ${ }^{5}$ and there are serious problems with the dates they record for lyric poets such as Alcman, Theognis, and Ibycus. ${ }^{6}$ A reexamination of the testimonia concerning Semonides is warranted in that so many scholars have appealed to them uncritically as providing firm evidence for a seventh-century date. ${ }^{7}$

${ }^{4}$ On this tradition generally, see the fundamental works of Diels, "Untersuchungen"; Rohde, "Studien zur Chronologie"; Jacoby, Apollodors Chronik. The most recent study of this tradition is Mosshammer's excellent Chronicle of Eusebius; his views are well summarized by the statement that "[Eusebius'] sources and the sources of the Suda were collateral branches of a vulgate chronology that derived from the Chronicle of Apollodorus, but transmitted a tradition contaminated by error, confusion, and false combination" (218).

${ }^{5}$ Hesiod's floruit is dated to 809 в.C. (Jerome Chron. AA1208 [p. 84 $\mathrm{c}$ Helm]; Porphyry ap. Suda, s.v. 'Hoíodos [ $\eta 583$ Adler]), Homer's to one hundred years earlier (Porphyry ibid.). For the sources of this tradition see Mosshammer, Chronicle of Eusebius 193-97.

${ }^{6}$ Alcman: Suda, s.v. 'A $\lambda x \mu \alpha \alpha^{2}$ ( $\alpha 1289$ Adler) dates Alcman to the twenty-seventh Olympiad (672-669 B.C.), whereas Eusebius gives two dates for his floruit, 659/58 (Jerome Chron. OL. 30.3 [p. 94i Helm]; Eusebius Chron. [Armenian version] AA1358 [p. 185 Karst]) and 609 (Jerome Chron. OL. 42.2 [p. 98 $\mathrm{Helm}$ ]). The last date is more likely to be accurate, since as West shows ("Alcmanica" 188-94), 5 fr. 2 col. i PMG connects Alcman with Spartan kings in power ca. 600 B.C.

Theognis: Jerome Chron. OL. 58.4 (p. 103' Helm), Eusebius Chron. (Armenian version) AA1471 (p. 189 Karst), and Cyril of Alexandria Contra Julianum 1.15 (Burguière

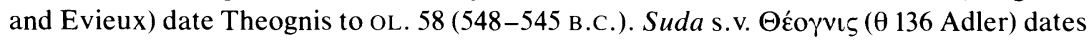
him to OL. 57 (544-541). But as the founder of a tradition of poetry, Theognis needs to be dated to the period of the tradition's earliest datable texts, which would put him ca. 620 B.C., around the time of Theagenes' rise to tyranny. See West, Studies 65-71; Legon, Megara 111; Figueira and Nagy, Theognis of Megara 1.

Ibycus: Suda s.v. 'I $\beta$ uxo ( ( 80 Adler), says that he came to Samos in OL. 54 (564561), during the reign of Polycrates father of Polycrates. But Herodotus (3.39) gives Polycrates' father a different name and says that Polycrates took power in a revolt. Jerome Chron. OL. 60.1 (p. 103 Helm), dates Ibycus' floruit to 540 B.C., which is closer to the reign of the younger Polycrates and thus more likely to be right. See Mosshammer, Chronicle of Eusebius 290-304, for a discussion of the many problems here.

${ }^{7}$ The evidence of the chronographers is defended by Pellizer, "Sulla cronologia" 17-23, and by Lloyd-Jones, Females of the Species 15-18, in a section full of historical errors and miscalculated dates. Trust in the chronographers seems also to be behind the identification of Semonides as "s. vii med." in West, Iambi et Elegi II 96. Some residual trust in the chronographers must be the reason for the reluctance to abandon a seventhcentury date altogether, even on the part of those who wish to make Semonides a little later than Archilochus (see note 2 above). 
Let me make my position clear at the outset. I believe that Testimonia I-IV, despite their differences in exact date, all derive from a common Alexandrian tradition which dated Semonides and other iambic poets in synchrony with Archilochus, whose recognizable historical allusions provided key dates around which to reconstruct a chronological schema. This dating of Semonides is therefore entirely conjectural and is based on no solid historical information within either his own work or that of early logographers. It should be trusted no more than the obviously incorrect dates which the same tradition generates for Hipponax and Aristoxenus of Selinus.

The earliest testimonium (I) is that of Clement of Alexandria, who makes the synchronism with Archilochus explicit, along with a statement that Callinus was not much earlier. The comparison of Archilochus and Callinus is amplified by the observation that Archilochus speaks of the Magnesians as having been destroyed (presumably by the Cimmerians), whereas Callinus has them still flourishing. Here we have an appeal to specific textual evidence of the sort modern scholars use in dating. What is significant for our purposes is that no such evidence is proffered for Semonides; the synchronism with Archilochus merely stands by itself, brief and uncorroborated. Indeed, Archilochus' date is used as a focal point for a number of chronological comparisons in this paragraph-not only with Semonides and Callinus, but also with Terpander and Eumelus.

The Chronicle of Eusebius (Test. II) also makes the synchronism with Archilochus explicit and adds a third iambic poet, Aristoxenus of Selinus. Although Epicharmus (fr. 88 Kaibel) calls Aristoxenus the earliest iambic poet, he was probably at least a generation later than Archilochus, since Selinus was not even founded until 625 B.C. ${ }^{8}$ In both Jerome's translation and the Armenian version (which omits Aristoxenus), it is Archilochus' name that begins the series and clearly provides the key date (OL. $29.1=664$ B.C.) to which the lesser iambists are attached. ${ }^{9}$ This technique is also evident in Eusebius' dating of Hipponax to OL. $23.1=688$ B.C. $\left(\right.$ p. $93^{\mathrm{e}}$ Helm); this is an alternative date in the Eusebian tradition for the acme of Archilochus (p. 67 ${ }^{\mathrm{a}} \mathrm{Helm} \sim$ p. 174

${ }^{8}$ See Thuc. 6.4. However, Diodorus Siculus 13.59 and even Eusebius himself (Jerome Chron. OL. 32.3 [p. $95^{\mathrm{f}} \mathrm{Helm}$ ]) date Selinus' foundation to 650 B.C.; this is still later than the floruit given here for Aristoxenus.

${ }^{9}$ See Mosshammer, Chronicle of Eusebius 214. 
Karst $\sim$ Georg. Syncellus 340$).{ }^{10}$ Of course, Hipponax' actual date was at least 150 years later, as is well documented both by internal and by external evidence. ${ }^{11}$ The synchronism with Archilochus may have been based on the comedy of Diphilus portraying Hipponax and Archilochus as rival lovers competing for the favor of Sappho (see Athenaeus $13.599 \mathrm{~d}) .{ }^{12}$ Or it may have been just another case of synchronizing to the same date poets whose genre and style seemed comparable. In either event, the manifest errors which this synchronistic methodology creates for Aristoxenus and Hipponax should lead us to question its application to Semonides.

We find the same confused synchronisms at work in Cyril's brief chronology of the iambic poets (Test. III). Although Archilochus is here identified with the earlier Eusebian date (OL. $23.1=688$ B.C.), the three lesser iambists are all brought together at the later Eusebian date for Archilochus (OL. $29.1=664$ B.C.). Again, the absurdity of the date for Aristoxenus and Hipponax suggests that this notice is also of no value for Semonides.

Although Archilochus does not figure by name anywhere in the notice of the Suda (Test. IV), he is probably the basis for the dates

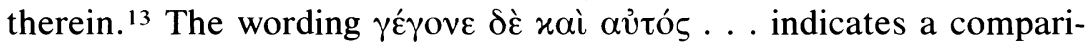
son with someone else's date in the Suda's source; the next sentence

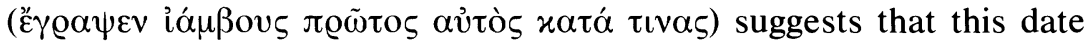
was extrapolated by comparison with the other major iambic poet who was often considered $\pi \varrho \tilde{\omega} \tau o \zeta$. The date 490 years after the Trojan War would, under Eratosthenes' conventional reckoning, be 694 B.C. However, a section of the entry under Simmias of Rhodes seems to have been derived from an earlier notice on Semonides and misplaced; this notice gives the even more preposterous date of 406 years after the Trojan War (= 778 B.C.). Rohde may be right in believing that the number has been corrupted in both notices from an original $496\left(v Q \varsigma^{\prime}\right)$, which would yield (lo and behold!) the year 688 B.C., the earlier of the two Eusebian dates for Archilochus.

\footnotetext{
${ }^{10}$ See Mosshammer, Chronicle of Eusebius 211-14, for the sloppy reasoning behind the double dating of Archilochus' acme.

11 Pliny NH 36.11 dates him to OL. 60 (540-537); the Parian marble (FGrH 239 A42) dates him ca. 550; Proclus ( = Test. V) dates him to the time of Darius, i.e., after 520.

${ }^{12}$ See Jacoby, Apollodors Chronik 146-47.

${ }^{13}$ For much of the following discussion I am indebted to Rohde, "Studien zur Chronologie" 559 n. 1, and Mosshammer, Chronicle of Eusebius 340 n. 5.
} 
Many critics have put great faith in the story which is coupled with the date 778 B.C., to the effect that Semonides was sent to Amorgos as the leader of Samian colonists settling the island. ${ }^{14}$ However, this story also bears a suspicious analogy to the career of Archilochus, whose poetry makes much of his role in the Parian settlement of Thasos. The date attached to the story is clearly of no authority, whether we accept it as it stands in the manuscripts or adopt Rohde's idea that it was originally 688. The statement about Semonides' founding three cities is also wrong, since only Minoa was a city of Samian foundation; we know that Aegiale and Arkesine were Naxian. ${ }^{15}$ Given these manifest historical errors, there is hardly any reason for supposing that this story had its source in any credible logographer. ${ }^{16}$ More likely, it is the usual construction of ancient vita tradition, perhaps designed to explain by analogy with Archilochus why Semonides was identified in some accounts as Amorgine and in others as Samian (see Test. V). ${ }^{17}$ Even if we were to accept that Semonides actually was a leader of Samian colonists, this datum would give no evidence of his date, since the date of Minoa's foundation is unknown and, in any event, nothing guarantees that Semonides emigrated as part of the first wave of colonists: colonization sometimes took place over a space of several generations, as is especially likely in this case, in view of Samos' tumultuous history throughout the sixth century. ${ }^{18}$ If Semonides did indeed emigrate from Samos to Amorgos, whether by himself or as part of a group, this is just as likely to have been due to Polycrates' tyranny or the Persian conquest as to any event in the seventh century.

It is not, I think, overstating the case to conclude that Testimonia I-IV are all absolutely worthless for determining the date of Semonides, based as they are on nothing more than an Alexandrian tradition

${ }^{14}$ See particularly Lloyd-Jones, Females of the Species 15-17.

${ }^{15}$ See Ruppel, "Amorginischen Städte" 313-15, who shows that the cities continued to maintain separate ethnic identities even as late as the third century B.C.

${ }^{16}$ The speculation of Lloyd-Jones, Females of the Species 17, that Semonides might have been mentioned by the obscure Samian chronicler Euagon, seems little more than wishful thinking.

${ }^{17}$ It could be that the idea of Semonides' Samian provenance derived entirely from his having written an Archaeology of the Samians, as the Suda attests (Test. IVв).

${ }^{18}$ On continuing relations between mother-cities and colonies long after the act of foundation, sometimes including the sending of additional settlers, see Graham, Colony and Mother City. As Graham notes $(74,162)$, Samos continued to maintain close ties with the far more distant colony of Perinthus even into the sixth century. There is no reason not to suppose that she would do the same with Amorgos. 
synchronizing him with Archilochus. But with Testimonium V, from Proclus' Chrestomathy, we see information which seems to be derived from an altogether different tradition: here the three major iambic poets are not synchronized together but are placed at different dates, each defined by association with a monarch. Archilochus is clearly identified as the first temporally ( $\delta \mu \dot{\varepsilon} v \pi \varrho \tilde{\omega} \tau \zeta \varsigma$ ) and is associated with Gyges, whom he mentions in his poetry (fr. $19 \mathrm{~W}$ ). Hipponax is the last in the series and is given his correct date in the late sixth century. Although Darius is not alluded to in our extant fragments of Hipponax, the dating by allusion to prominent monarchs rather than by artificially constructed years of acme does suggest a careful and reliable method based on historical evidence in the texts themselves. Unfortunately, the testimony for Semonides here is obscured by corruption: there was no Macedonian king by the name of Ananius or Ananias. However, Ananias was the name of no fewer than three New Testament characters (Acts 5:1, 9:10, 23:2) and could thus easily be misread into a text by a Byzantine scribe. The easiest emendation paleographically is Sylburg's

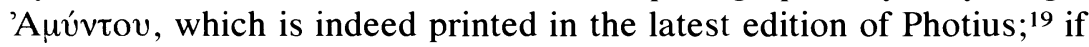
correct, this would put Semonides in the late sixth century along with Hipponax, since Amyntas' reign lasted from 540 to 498. But the corruption prevents us from appealing to this testimonium as a certain piece of evidence: the most that we can say in the present state of our knowledge is that Proclus' source may have assigned Semonides a late sixth-century date. ${ }^{20}$ The question of Semonides' date must, if possible, be decided on the basis of internal evidence.

\section{SEMONIDES AND ELEMENTAL THEORY}

The Earth-woman and Sea-woman have always been considered a surprising disruption in Semonides' poem on the female types, who

${ }^{19}$ Henry, Photius V 158. For support of this emendation see also Severyns, Recherches I 151-54, II 111-12. Clinton's emendation to 'A@ $\gamma \alpha$ íov is far less attractive paleographically, but necessary for those who wish to produce a seventh-century date.

${ }^{20}$ Another possible, although in my opinion less likely, explanation of the corruption could be that the minor choliambic poet Ananius originally formed part of this list in Proclus' source and his name somehow became confused with the name of the king

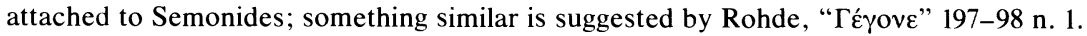
This would involve a much earlier and more extensive corruption of the text than under the Byzantine hypothesis I have proposed above. 
are otherwise modeled on animal species. ${ }^{21}$ Commentators have usually attributed their presence to the influence of Hesiod, Works and Days 60-61, where Pandora is created by Hephaestus through mixing earth and water. ${ }^{22}$ But Semonides is proposing something quite different here-not a woman made out of the constituent elements of all matter, but two different women, each dominated by a single element which influences her psychic disposition. The Earth-woman is stupid, eats all the time, and is too lazy even to draw her chair near the fire during cold weather; the Sea-woman is beautiful, unpredictable, alternately well disposed and ferocious, impossible to handle. The former is solid and unmoving, the latter liquid and unstable. What is striking here is not that Semonides had a knowledge of earth and sea as elements, but that he makes each element the basis for description of a certain psychological profile. The idea of constituent elements as an influence on human behavior is far too bold and rationalistic to have been the invention of Semonides, not otherwise known as an original thinker. It must reflect the influence of Ionian speculation about elemental interaction and its effects on the human psyche.

Fraenkel is alone among previous commentators in recognizing this passage as a reflection of Ionian elemental theory. ${ }^{23}$ But his reluctance to challenge the consensus on a seventh-century date for Semonides led him to misidentify the source of influence as the cosmological doctrine of Thales. ${ }^{24}$ None of our information about Thales suggests that he was a dualist or that he had any concept of the elements as determinative for human character.

It is rather with the famous dike fragment of Anaximander (A9, B1 DK) that we first see the idea of nature as a dynamic equilibrium between opposites, particularly as reflected in the elements: if one ele-

${ }^{21}$ For a general appreciation of their significance and place within the poem see Marg, Der Charakter 16-18, and Pellizer, "La donna del mare." There is little support today for Opitz's idea, "Weiberspiegel" 16-30, that they are interpolated from another poem based on the four elements.

${ }^{22}$ See Marg, Der Charakter 17; Kakridis, "Weiberiambus" 5; Verdenius, "Semonides über die Frauen" 138-39; Lloyd-Jones, Females of the Species 69.

${ }^{23}$ Fraenkel, "A Thought Pattern" 332-33 and Early Greek Poetry 205-6.

${ }^{24}$ Since Thales is generally dated in relation to the solar eclipse of 585 , this would put Semonides very late in the seventh century if there at all. At the very least, the traditional chronographic reckoning of his date would have to be abandoned. 
ment or quality exists in superabundance, it must pay "justice" to its opposite in a perpetual cycle of readjustment. ${ }^{25}$ Later in the sixth century, Xenophanes extends this doctrine into a strong dualism of earth and water as the fundamental elements of all things (B29 DK, $\gamma \tilde{\eta}$ xai

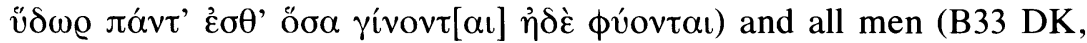

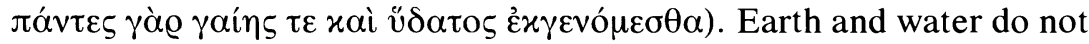
exist in a static proportion, however, but are constantly changing as the world moves through alternating cycles of dry and wet (A32, $33 \mathrm{DK}$ ); this cyclical process, clearly derived from empirical observation of the seasons in Greece, embodies the same principle of compensatory variation as is evident in Anaximander's dike fragment.

In Xenophanes we see the idea that men are composed out of earth and water, and the concept that these two substances can alternate with each other in quantity. But it is only with Alcmaeon of Croton that we find an explicit theoretical formulation of the consequences of this alternation for the human organism:

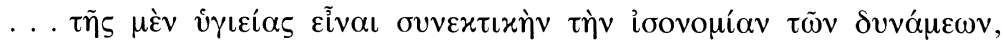

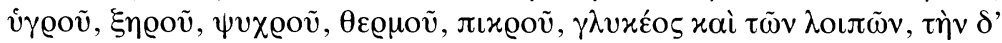

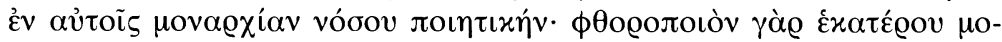

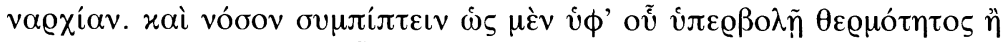

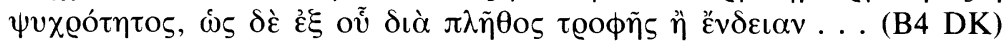

Health is generated by the balance and equality (isonomia) of contraries, whereas disease is produced by the dominance (monarchia) of one quality over the other. Although Alcmaeon does not deal with elements such as earth and water per se, he does emphasize their qualitative correlates "dry" and "wet," which he puts first in his list of exemplary contraries. Second in his list are "cold" and "hot." Lloyd has demonstrated at some length that these two linked pairs of qualities form the basis for later cosmological and physiological speculation among the Presocratics and earliest Hippocratic treatises. ${ }^{26}$

The linkage of these four qualities seems to be alluded to in the text of Semonides' portrayal of the Earth-woman:

${ }^{25}$ On this fragment and the elemental nature of Anaximander's opposites see Vlastos, "Equality and Justice" 168-76; Kahn, Anaximander 166-96; Lloyd, "Hot and Cold" 94-98.

${ }^{26}$ Lloyd, "Hot and Cold." 


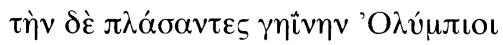

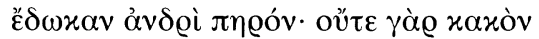

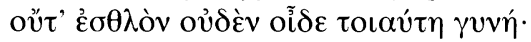

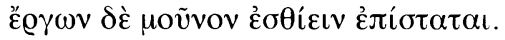

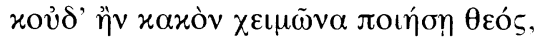

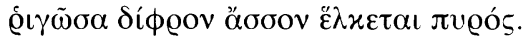

(fr. $7.21-26 \mathrm{~W}$ )

The Earth-woman prefers to freeze rather than draw near the fire. Earth (the "dry" element) is associated with coldness inasmuch as the solid, earthly form of water is of course ice. It is at the opposite end of the elemental spectrum from fire, which is the hottest, most rarefied and unstable of all the elements (cf. Heraclitus B36, 76 DK). Within the polarity of earth and water, earth is the "cold" term and water the "hot": indeed, the idea that water and warmth are connected as the origin of life goes back to Thales (cf. Aristotle Metaphysics 983b23-24) and Anaximander (A11 DK). ${ }^{27}$ Semonides' detail about the Earth-woman's indifference to fire and warmth can only be understood in the context of such elemental theories.

Alcmaeon's date is itself a matter of some controversy, but there is no real reason to doubt Aristotle's testimony that he was active during the old age of Pythagoras. ${ }^{28}$ The chronographic tradition identifies Pythagoras' floruit with the rise to power of Polycrates around 530 B.С. ${ }^{29}$ this is probably not far from the truth and would suggest a floruit for Alcmaeon somewhere in the last quarter of the sixth century. Indeed, Alcmaeon's theory may well have owed something to Pythagorean influence. Although not generally considered a Pythagorean himself, Alcmaeon doubtless came into contact with Pythagoras' teachings and disciples in Croton. For the Pythagoreans, the soul seems to have been regarded as an "attunement" ( $\left(\varrho \mu \mu^{\prime} \alpha\right)$ between opposite qualities which are held in appropriate numerical proportions. As the Pythagorean Simmias of Thebes expresses it in Plato's Phaedo:

${ }^{27}$ For later extensions of this doctrine in the Hippocratic corpus and elsewhere see Lloyd, Polarity and Analogy 57 n. 3. Empedocles (A73 DK) held that sea animals were warm-natured, land animals cold-natured.

${ }^{28}$ Aristotle Metaph. 986a27-34. See the discussion of Guthrie, History I 341-43.

${ }^{29}$ Jerome Chron. OL. 62.3 (p. 104 Helm); Eusebius Chron. (Armenian version) AA1484 (p. 189 Karst). Pythagoras' death is dated to 497 by Jerome Chron. OL. 70.4 (p. $107^{\mathrm{f}} \mathrm{Helm}$ ), to 499 by the Armenian version of Eusebius Chron. AA1517 (p. 191 Karst). 


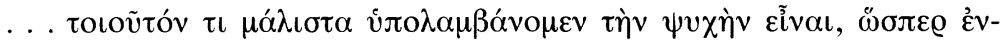

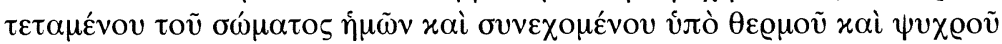

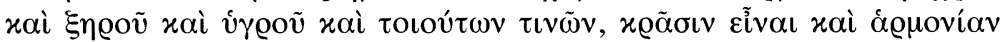

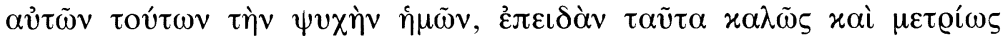

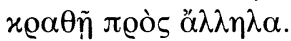

$(86 b-c)$

This passage has been a source of controversy, since the doctrine which Simmias goes on to expound about the soul's dissolution cannot be genuinely Pythagorean. ${ }^{30}$ But his initial statement that the soul is a harmonia of opposites expresses a concept elsewhere attested as Pythagorean. ${ }^{31}$ Its similarity to Alcmaeon's formulation of bodily health as the proper isonomia of these same opposites (hot and cold, dry and wet) suggests that this doctrine may be quite early in the history of Pythagoreanism, even going back to the founder himself, who, like Semonides, began his career in Samos.

The concept of harmonia between opposed forces is taken for granted by Heraclitus (B51 DK), although not specifically in connection with the soul. Heraclitus was, however, interested in the soul and the effects of opposed qualities on it. For Heraclitus, there was constant

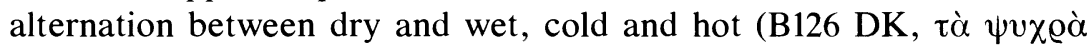

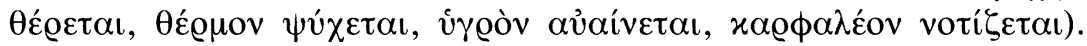
But most important for our purposes are Heraclitus' reflections on wet and dry souls. Psyche for Heraclitus is "breath" as well as "soul," and is thus a form of air in elemental terms. Hence Heraclitus, with his usual sense for paradox, can declare that "becoming moist is either

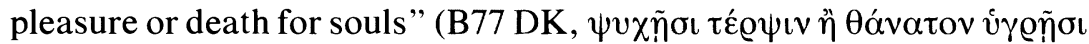
$\gamma \varepsilon v \varepsilon \dot{\sigma} \theta \alpha \mathrm{l})$, a pleasure in the form of drunkenness, but a death in the sense of ceasing to be "breath" and instead becoming the heavier element of water (cf. B36, 76 DK). He elaborates the image of the wet soul further in B117 DK: "whenever a man is drunk, he is led stumbling along by a young boy, not understanding where he is going, having a moist soul." Wetness of soul leads to a dulled sense of perception, like drunkenness; lacking his perceptual faculties, the wet man is less of a

${ }^{30}$ For a convenient summary of the controversies surrounding this passage see Guthrie, History I 309-17.

${ }^{31}$ This part of Simmias' view is reaffirmed by the Pythagorean Echecrates later in the dialogue (Phaedo $88 \mathrm{~d}$ ). In connection with Pythagoras himself see Macrobius Somn. Scip. 1.14.19. On Pythagorean harmonia doctrine in general see Meyer, APMONIA, 9-13. 
man, but is conducted even by a small boy. The opposite state of the

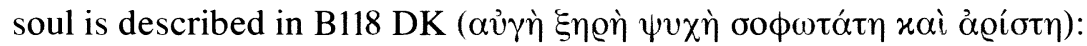
"a ray of light is the dry soul, wisest and best." Instead of dulled perceptions, the dry soul is associated with wisdom and clarity: a ray of light, it is closer in form to (though not identical with) the cosmic fire which is at the heart of Heraclitus' logos. We thus see a convergence of the elemental, physiological, psychological, and metaphysical levels in Heraclitus; Sextus Empiricus (Adv. Math. 7.129-30 = A16 DK) attests Heraclitus' interest in the physiological/psychological dimensions of perceiving the logos, and Heraclitus' fragment on sleeping and waking (B26 DK) gives evidence of the same.

Of course, Heraclitus' treatment of the wet and dry souls does not correspond in detail to Semonides' Sea-woman and Earth-woman. But it does suggest a similar mechanism for looking at psychological phenomena in elemental terms. The cryptic and imagistic style of Heraclitus' aphorisms on this topic indicates that it was a doctrine already familiar to his audience: "the moist-dry contrast in Heraclitus' psychophysics is not original; he takes it for granted as the theory current in 'scientific' circles of his own time and place. What is distinctly Heraclitean is the enrichment of this physical doctrine with figurative and poetic overtones. . . . These images serve not merely as an ornament of style but as the symbolic expression for a rigorous correlation between physical and moral-intellectual states of the psyche." 32

The connection between the balance of humors and matters of health and temperament becomes fundamental in fifth-century Hippocratic writings. In a very detailed and exhaustive study of the origins and background of humoral theory, Thivel concludes that the fully developed theory of four humors was preceded by a theory of two basic humors (phlegm and bile), which antedates even our earliest extant medical writings and was probably under formation during the course of the sixth century, pari pass $u$ with the development of Ionian meteorology and philosophy. ${ }^{33}$ In his view, this theory is already presupposed as traditional by Alcmaeon of Croton. The bile/phlegm opposition is certainly comparable in nature to the wet/dry, hot/cold oppositions so fundamental for Xenophanes, Alcmaeon, and Heraclitus. Indeed, bile

${ }^{32} \mathrm{Kahn}$, Heraclitus 248 . Heraclitus' valuation of terms is certainly paralleled in the Hippocratic corpus: Ulc. 1 clearly defines the dry as healthy, the wet as unhealthy.

${ }^{33}$ Thivel, Cnide et Cos? 289-383, esp. 295-96, 305-6, 345-46. Thivel's views were in some ways adumbrated by Fredrich. Hippokratische Untersuchungen 33-50. 
is frequently associated with inner heat, phlegm with inner coldness. ${ }^{34}$ The early treatise On Glands, based on a system of these two humors,

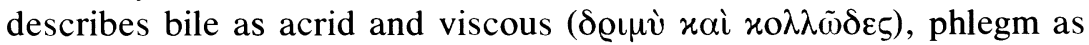

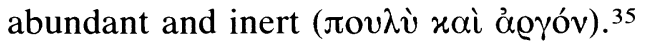

These physical qualities of the humors themselves correspond to their effects on humans. Airs, Waters, and Places characterizes phlegmatics as flabby, with soft, loose bellies, while the bilious are slender and of a ferocious disposition; because of their inner coldness, phlegmatics live in cities exposed to hot winds, whereas the inner heat of the bilious causes them to live in cities exposed to cold winds. ${ }^{36}$ This distinction is clearly cognate to that which the treatise makes at the end between the inhabitants of mild climates, who are fleshy, indolent, and dull, and the inhabitants of harsh climates, who are slender, clever, industrious, haughty, and fierce. ${ }^{37} \mathrm{Phlegm}$ is commonly associated with various forms of bodily edema and with immobility of the limbs. ${ }^{38}$ The treatise On Diseases discusses the "phlegmatic disease," usually afflicting females, as a life-long state of corpulence and weakness, lack of energy, and a tendency to eat all the time. ${ }^{39}$ The treatise On the Sacred Disease differentiates the effects of the two humors by declaring that those whose brains are deranged by an excess of phlegm are driven to speechlessness and stupor, whereas those with brains deranged from an excess of bile are vociferous, malignant, and hyperactive; phlegm cools the brain beyond the norm, whereas bile heats it beyond the norm. ${ }^{40} \mathrm{We}$ can see that these two temperaments bear a remarkable resemblance to Semonides' two elemental types: the Earth-woman is phlegmatic (quiet, slow-moving, cold-natured, fat), the Sea-woman is bilious (noisy, always in motion, hot-tempered, beautiful).

${ }^{34}$ For the association of bile with heat and fever see Aer. 9, Acut. app. 1, Morb. 1.7, 1.29, 2.40. For the coldness of phlegm see Morb. 1.24, 2.8. Aer. 7 says that stagnant, marshy waters form bile in the summer, when hot, and phlegm in the winter, when cold. Also see the references in the paragraph below.

${ }^{35}$ Gland. 7, and Thivel, Cnide et Cos? 304-5.

${ }^{36}$ Aer. 3-4, 7.

${ }^{37}$ Aer. 24. Verdenius, "Semonides über die Frauen" 139, notes the parallel between these two types and Semonides' elemental women, but does not make any inferences from the parallel.

${ }^{38}$ Edema: Morb. 2.1, 2.71, Int. 21, 50. Immobility: Int. 20.

${ }^{39}$ Morb. 2.70.

${ }^{40}$ Morb. Sacr. 10, 18. Morb. 2.22 also associates bile with rage and raving. Int. 48 says that bile collecting in the liver will induce hallucinations and delirium. 
One additional influence which may have contributed to Semonides' identification of character types with the elements was the growth of allegorical exegesis during the late sixth century. In this period, Theagenes of Rhegium was known to have explained the Homeric gods in terms of moral and elemental allegories. The scholiastic notice concerning Theagenes suggests that he was particularly interested in the Theomachia of Iliad 20 in these terms: ${ }^{41}$ Hephaestus is fire, Poseidon water, Hera air, Apollo the sun, Artemis the moon, Ares madness, Aphrodite desire, Leto forgetfulness. Delatte and Detienne have seen Theagenes' mode of exegesis as derived from the Pythagoreans; Detienne in particular thinks it unlikely that a "grammarian," as Theagenes is identified, could by himself have originated both moral and elemental modes of allegorical exegesis. ${ }^{42}$ We have good evidence for this kind of interpretation even in the non-Pythagorean Xenophanes' description of Iris as a multicolored cloud (B32 DK). Whether Pythagorean or not, interpretation of the Homeric gods as elements or forces of nature is fully consistent with the augmented sixth-century interest in the elements as cosmological and psychological principles. It is also significant that elemental allegory is never completely divorced from moral exegesis. This tradition affords a clear precedent for Semonides' idea of using the elements Earth and Sea as a basis for human character types.

To summarize my conclusions, there are at least three interconnected strands of influence which lie behind the concepts of elemental psychology evident in Semonides' Earth-woman and Sea-woman. As we have seen, cosmological speculation beginning with Anaximander emphasized the balance of qualities or elements; this was applied to a dominant dualism of Earth and Water by Xenophanes and extended into the psychological dimension by Heraclitus. Alcmaeon of Croton and early medical theory identified bodily health as an appropriate balance of qualities or humors, sickness as the undue domination of one; character types may be defined by a tendency to prevalence of one humor, with the phlegmatic type being lazy, fat, and dull (like the Earth-woman), the bilious type hyperactive, slender, and fierce-tem-

${ }^{41} \Sigma^{\mathrm{B}}$ Il. 20.67 (Dindorf). On Theagenes see Delatte, Etudes 114-15; Buffière, Mythes d'Homère 103-5; Detienne, Homère, Hésiode 65-67; Svenbro, La parole et le marbre 108-38.

${ }^{42}$ In addition to Delatte, Etudes 109-36, and Detienne, Homère, Hésiode passim, see Boyancé, Culte des Muses 121-31, and Lamberton, Homer the Theologian 31-43, for early Pythagorean interest in Homeric allegory. 
pered (like the Sea-woman). Finally, allegorical interpretation of Homer may have provided the inspiration for Semonides' conceiving character types specifically in terms of the elements. All three of these intellectual currents seem to have become well developed by the last quarter of the sixth century, and it is within this theoretical context that Semonides' elemental women clearly belong. The critical link among all three may well have been Semonides' fellow Samian Pythagoras, although the uncertain nature of our evidence concerning Pythagoras' doctrines prevents any positive conclusions. As the case of Xenophanes demonstrates, the interconnections between poetry and philosophy in late sixth-century Ionia were intimate. It is far more reasonable to suppose Semonides influenced by these doctrines than to think that he originated the key features of elemental psychology on his own at some point in the seventh century or that these ideas were already implicit in early folk tradition, finding expression in his poetry alone before their theoretical formulation in the late sixth century.

\section{THE ANIMAL-WOMEN AND TRANSMIGRATION}

There is one other aspect of Semonides' poem on women that may connect it to late sixth-century philosophical speculation, although I regard it as less certain. Aside from the Earth-woman and Sea-woman, all the other female types are identified as having been made by the god from a certain animal-pig, fox, dog, ass, weasel, horse, ape, bee. Each paragraph begins with a formula like tìv $\delta$ ' $\dot{x} x$. . . , with the subject and verb understood from line 7 as $\theta \varepsilon \dot{s} \varsigma$ है $\theta \eta x \varepsilon$. Semonides does not say that these women are like the animals (in the manner of a Homeric simile), nor does he present them as actually being animals (in the manner of a fable). Instead, they are human women, set (" $\varepsilon \eta x \varepsilon)$ into human form from ( $\dot{\varepsilon} \varkappa$. . .) an animal through the agency of the god ( $\left.\theta \varepsilon \varepsilon_{\varsigma}\right)$ and retaining some of that animal's traits. Nowhere in earlier Greek literature or myth do we hear of humans being made or born from animals, whether with divine help or not. There is certainly nothing like it in Hesiod. Rather, the inspiration is more likely to have been the one doctrine we can with certainty ascribe to Pythagoras himself: the transmigration of souls between human bodies and animal bodies. ${ }^{43} \mathrm{It}$ is here and only here in early Greek thought that we have animals changing into

${ }^{43}$ The identification of this doctrine with Pythagoras himself is made certain by Xenophanes (B7 DK). 


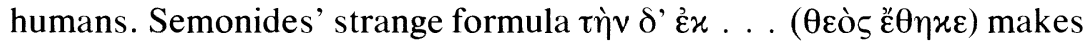
sense best if we see the women as humans whose souls formerly occupied animal bodies; the verb tí $\eta \mu \iota$ seems especially appropriate for this divinely supervised movement of the soul. Under any other interpretation, it is difficult to understand why Semonides chose this distinctive formula rather than a more straightforward simile or metaphor.

\section{METRICAL CONSIDERATIONS}

The most distinctive metrical feature of Semonides' iambic trimeter is his complete avoidance of resolution. This compares with a frequency of about 10 percent (i.e., one resolution every ten lines) in Archilochus, Hipponax, and the earliest plays of Aeschylus. ${ }^{44}$ Since we see the same frequency of resolution both in the two major iambic poets of two different centuries and also in our earliest extant Greek tragedies, we may be justified in seeing the 10 percent frequency as a normative rate for the archaic period, crossing generic lines. Was Semonides' complete avoidance of resolution more likely to be a sign of early and primitive metrical technique or of metrical refinement and sophistication? While it is impossible to be certain in such matters, I regard the latter answer as the more likely. Even if we date Semonides to the midseventh century, he would have been contemporary with Archilochus, who did employ resolution; it seems unlikely that the technique of using resolution would be unknown to an iambic poet at this time. On the other hand, after two centuries or more of development, one could well imagine poets' fluency with the trimeter form reaching the point that one of them decides that resolution is unneeded for his composition and that a purely iambic flavor is better retained in his verse. That less use of iambic resolution was considered a desirable objective by sophisticated poets is suggested by the development of Aeschylus' style in this regard: his earliest extant play, Persians (472 B.C.), has 11.0 percent resolution, the Seven Against Thebes (467) 9.3 percent, Suppliants (ca. 463) 8.4 percent, and the three plays of the Oresteia (458) range between 4.8 and 5.2 percent. ${ }^{45}$ Even as talented a versifier as Aeschylus seems to have been unable to get by without some use of resolution (at about a 5

${ }^{44}$ For the iambographers see West. Studies 115 . Solon's frequency is about 3.4 percent, but his sample (two resolutions in fifty-nine lines) may be too small to bear much statistical significance. For resolution in Aeschylus see Garvie, Aeschylus' Supplices $32-36$.

${ }^{45}$ The figures are those of Garvie, Aeschylus' Supplices 33. 
percent level), despite his clear desire to minimize its use. ${ }^{46}$ Semonides' achievement in purging it from his verse altogether should therefore not be minimized. It is more reasonably seen as the culmination of a long tradition of writing in iambic verse than as its beginning. It is in keeping with the same spirit of late sixth-century experimentation and variation that Hipponax conceived the idea of altering the trimeter's verse end and created the choliambic meter.

\section{THE DATE OF FRAGMENT 29D}

The notice of the Suda (Test. IV[A]) tells us that Semonides also wrote elegies in addition to his iambic poetry, but the only elegiac poem commonly attributed to him is fr. 29D, a highly disputed text:

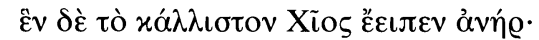

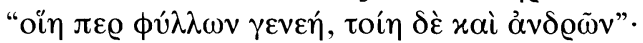

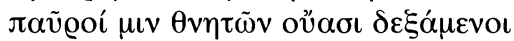

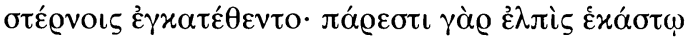

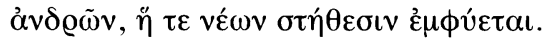

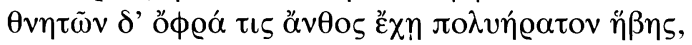

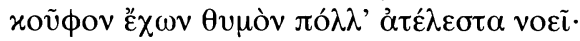

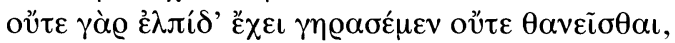

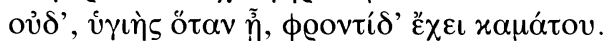

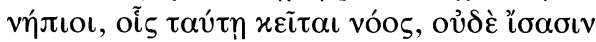

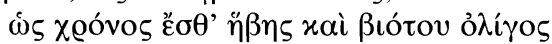

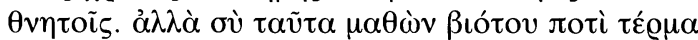

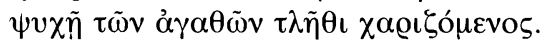

This poem, like all of Semonides' fragments, is attributed to "Simonides" by Stobaeus. Since Simonides of Ceos also wrote elegies (all funeral epitaphs), there have been those who regard this poem as his. ${ }^{47}$ But this poem shows little of the intellectual subtlety and ambiguity

${ }^{46}$ The same appears to have been true of the other two tragedians as well. Sophocles' resolution frequency varies, but averages about 6 percent (Electra being the lowest at 3.4 percent). In Euripides' earliest datable plays we see frequencies of 6.2 percent (Alcestis), 6.6 percent (Medea), and 4.3 percent (Hippolytus); of course, Euripides greatly increased his use of resolution during the last twenty years of his career, but this was a matter of conscious use of resolutions for dramatic effect. The figures are taken from Ceadel, "Resolved Feet" 70, 85 n. 2.

${ }^{47}$ See Crusius, "Zur Kritik" 715, and, more recently, Garner, From Homer to Tragedy 2. 
which one expects from Simonides. Fraenkel and West have argued that the language is more characteristic of the late sixth century than of the seventh (to which they assign Semonides); accordingly, they have seen the poem as part of a funeral epitaph and have assigned it to an anonymous poet of Simonides' time whose work became part of the "Simonidean" collection of epitaphs. ${ }^{48}$ However, the problem with both this view and the idea that it is a genuine work of Simonides is that the tone, content, and length of this fragment are not at all consistent with the Simonidean epitaphs. It is far more in keeping with traditional deliberative elegy as practiced by Mimnermus, Archilochus, Solon, Theognis, and others.

Indeed, the relationship between Mimnermus fr. $2 \mathrm{~W}$ and this poem is highly relevant to the questions of date and authorship. Both poems take as their starting point Glaucus' famous line on the races of men and the leaves (II. 6.146) and elaborate from it a contrast between ignorant youth and painful old age. The two poems are sufficiently close that one must have been meant as a response to the other. Defending Semonidean authorship of fr. 29D (and assuming the usual mid-seventh-century date), Babut has argued that Mimnermus wrote in response to Semonides: he sees Mimnermus' message as more positive, with youthful ignorance of the future being the cause of happiness, whereas Semonides viewed youthful hopes as vain delusions. ${ }^{49}$ But this praise of blissful ignorance in the young is not really made explicit in Mimnermus' text and is at most an inference from the cryptic and am-

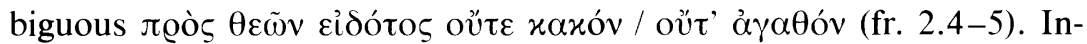
deed, the end of Mimnermus' poem (fr. 2.15-16) is decidedly fatalistic and pessimistic; it is hardly what we would expect if, as Babut argues, this poem is meant to be more positive than its predecessor.

I believe that the relationship between the two texts makes more sense if we regard the "Semonidean" fr. 29D as the later of the two. While there is nothing polemical in the opening of Mimnermus fr. $2 \mathrm{~W}$,

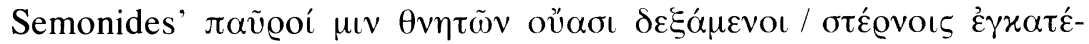
$\theta \varepsilon v \tau o$ (lines 3-4) clearly implies that the Homeric line he has just quoted is a tag frequently heard and bandied about, but seldom understood in its full implications; this line makes far more sense if the poem

${ }^{48}$ Fraenkel, Early Greek Poetry 207 n. 14, and West, Studies 179-80. This view is tentatively endorsed by Lloyd-Jones, Females of the Species 97.

${ }^{49}$ Babut, "Sémonide et Mimnerme" 32-40. For a very different conception of Mimnermus' view of youth in this text see Schmiel, "Youth and Age" 289. 
is itself a response to an earlier poem using the same tag. Unlike the fatalistic, negative ending of Mimnermus' poem, Semonides' text ends with a positive exhortation to hedonism. Semonides unpacks the cryp-

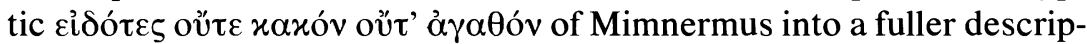
tion of both sides of what the young ignore: the unpleasantness of old age and death (lines 8-9 = Mimnermus' xaxóv) and the brief pleasure

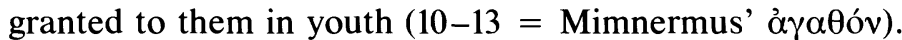

The problematic issues surrounding fr. 29D can all be resolved if we accept a late sixth-century date for Semonides. We can preserve the fragment as Semonidean, as suggested by its close match in tone and message with the iambic fr. $1 \mathrm{~W}$. We can see it as a response to Mimnermus fr. $2 \mathrm{~W}$, as argued above-something impossible under the traditional chronographic reckoning of Semonides' date. ${ }^{50}$ And we can meet the one serious objection to Semonidean authorship put forward by modern critics: the feeling that its vocabulary is closer to that of the late sixth or even the fifth century.

\section{SEMONIDES 7 AND PHOCYLIDES FRAGMENT 2D}

Another problematic intertextual issue is the relationship between Semonides' poem on women and Phocylides fr. 2D:

\begin{tabular}{|c|}
\hline 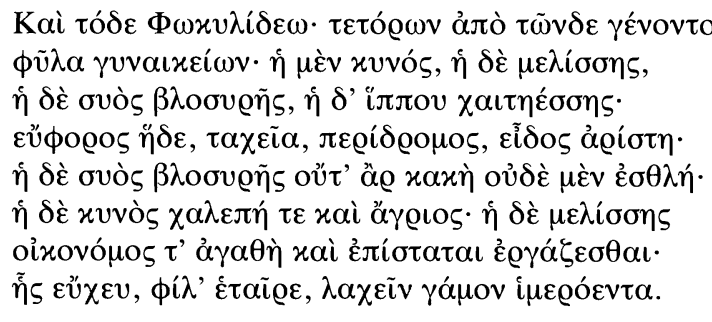 \\
\hline
\end{tabular}

Traditional assumptions about the date of Semonides have led scholars to conclude that Phocylides' poem must be a derivative spinoff putting Semonides' idea into a pithy, gnomic formulation. ${ }^{51}$ The parallels between the two poems do indeed seem close enough to justify a direct

\footnotetext{
${ }^{50}$ Mimnermus' poetic activity is generally dated to the second half of the seventh century; see West, Studies 72-74. Fr. 2W must have been a work of his old age and thus datable toward the end of the century.

${ }^{51}$ See Marg, Der Charakter 40 n. 45, and Gerber, Euterpe 257.
} 
connection of influence: both characterize the Horse-woman as beautiful, both list the Bee-woman last and make her an industrious housewife. But one wonders whether the relation of influence does not in fact move in the opposite direction from that which scholars have taken for granted. If Phocylides genuinely had before him Semonides' colorful descriptions of the filthy Pig-woman (7.2-6) and the nosy, meddlesome Dog-woman (7.12-20), it seems that he would have found a more imaginative way to describe the former than as merely "neither bad nor good" and a more apt characteristic of the latter than "difficult and wild." One is also tempted to question whether the relatively neutral tone of Phocylides' poem (two good types, one indifferent, one bad) would be possible after the woman/animal analogies had been used in such a devastating way by Semonides. It makes better sense to suppose that Semonides found in Phocylides' aphorism the inspiration for classifying women as animal types, rephrased the relationship in terms more evocative of Pythagorean metempsychosis (see section 3), borrowed the interesting and apt characterizations of the Horse-woman and Bee-woman, improved upon Phocylides' rather pale characterizations of the Pig-woman and Dog-woman, added several new types, including the two elemental women, and expanded the whole conception into a much longer and more impressive poem reflecting a pervasively pessimistic view. Poems written in imitation of earlier poems aim to be better than their models, not inferior.

The chronographic tradition dates Phocylides of Miletus contemporary with Theognis, giving his floruit as 544-541 B.C. ${ }^{22}$ This synchronistic dating is itself open to suspicion on grounds similar to those we have advanced for doubting the synchronism of Semonides and Archilochus. Accordingly, it does not help us date Semonides conclusively to know that he followed Phocylides rather than vice versa. But the possibility of Phocylides' influencing Semonides obviously becomes greater the later we place Semonides in archaic poetic tradition.

While none of the arguments I have presented in the last four sections is by itself definitive, I believe that the cumulative effect of all these considerations, taken together with those of sections 1 and 2, is to suggest that there is a serious case for rejecting the traditional date our chronographic sources assign Semonides and instead seeing him as a

${ }^{52}$ Suda s.v. $\Phi \omega x v \lambda i \delta$ † ( $\phi 643$ Adler). 
poet of the late sixth century, coeval with Xenophanes and Heraclitus. Those who have studied the chronographic sources for very long cannot fail to come away from them with profound misgivings about their reliability in cases like this one, where a poet is dated purely by synchronism with another writing in the same genre. Nevertheless, critics have balked at a substantial revision of Semonides' date for want of real evidence. In the words of one, "there seems to be no adequate reason for rejecting a seventh-century date." 53 I hope to have suggested in this essay that there are indeed some adequate reasons for doing so.

University of Texas, Austin

THOMAS K. HubBaRd

\section{BIBLIOGRAPHY}

Babut, Daniel. "Sémonide et Mimnerme." REG 84 (1971) 17-43.

Boyancé, P. Le culte des Muses chez les philosophes grecs. Paris: E. de Boccard, 1937.

Buffière, F. Mythes d'Homère et la pensée grecque. Paris: Les Belles Lettres, 1956.

Campbell, David A. Greek Lyric Poetry. London: Macmillan, 1967.

Ceadel, E. B. "Resolved Feet in the Trimeters of Euripides and the Chronology of the Plays." CQ 35 (1941) 66-89.

Crusius, O. "Zur Kritik der antiken Ansichten über die Echtheit homerischer Dichtungen." Philologus 54 (1895) 710-34.

Delatte, A. Etudes sur la littérature pythagoricienne. Paris: E. Champion, 1915.

Detienne, Marcel. Homère, Hésiode, et Pythagore. Brussels: Collection Latomus, 1962.

Diels, Hermann. "Chronologische Untersuchungen über Apollodors Chronika." RhM 31 (1876) 1-60.

Easterling, P. E. "Semonides." In The Cambridge History of Greek Literature, edited by P. E. Easterling and B. M. W. Knox, I.1 112-26. Cambridge: Cambridge University Press, 1989.

Figueira, Thomas J., and Gregory Nagy. Theognis of Megara: Poetry and the Polis. Baltimore: The Johns Hopkins University Press, 1985.

Fraenkel, Hermann. Early Greek Poetry and Philosophy. Translated by M. Hadas and J. Willis. Oxford: Basil Blackwell, 1975.

. "A Thought Pattern in Heraclitus." AJP 59 (1938) 309-37.

${ }^{53}$ Gerber, Euterpe 53. 
Fredrich, C. Hippokratische Untersuchungen. Philologische Untersuchungen, 15. Berlin: F. Weidmann, 1899.

Garner, Richard. From Homer to Tragedy: The Art of Allusion in Greek Poetry. London: Routledge, 1990.

Garvie, A. F. Aeschylus' Supplices: Play and Trilogy. Cambridge: Cambridge University Press, 1969.

Gerber, Douglas E. Euterpe: An Anthology of Early Greek Lyric, Elegiac, and Iambic Poetry. Amsterdam: A. M. Hakkert, 1970.

Graham, A. J. Colony and Mother City in Ancient Greece. 2d ed. Chicago: Ares, 1983.

Guthrie, W. K. C. A History of Greek Philosophy. Cambridge: Cambridge University Press, 1962.

Henry, R., ed. Photius: Bibliothèque. Paris: Les Belles Lettres, 1967.

Jacoby, Felix. Apollodors Chronik. Philologische Untersuchungen, 16. Berlin: F. Weidmann, 1902.

Kahn, Charles H. Anaximander and the Origins of Greek Cosmology. New York: Columbia University Press, 1960.

- The Art and Thought of Heraclitus. Cambridge: Cambridge University Press, 1979.

Kakridis, Johannes T. "Zum Weiberiambus des Semonides." Wiener Humanistische Blätter 5 (1962) 3-10.

Lamberton, Robert. Homer the Theologian. Berkeley and Los Angeles: University of California Press, 1986.

Legon, R. B. Megara: The Political History of a Greek City-State. Ithaca: Cornell University Press, 1981.

Lesky, Albin. A History of Greek Literature. Translated by J. Willis and C. de Heer. New York: Thomas Y. Crowell, 1966.

Lloyd, G. E. R. "The Hot and the Cold, the Dry and the Wet in Greek Philosophy." JHS 84 (1964) 92-106.

- Polarity and Analogy: Two Types of Argumentation in Early Greek Thought. Cambridge: Cambridge University Press, 1966.

Lloyd-Jones, Hugh. Females of the Species: Semonides on Women. Park Ridge: Humanities Press, 1975.

Marg, Walter. Der Charakter in der Sprache der frühgriechischen Dichtung. Würzburg: Konrad Triltsch, 1938.

Meyer, P. Bonaventura. APMONIA: Bedeutungsgeschichte des Wortes von Homer bis Aristoteles. Zurich: Gebr. Leemann, 1932.

Mosshammer, Alden A. The Chronicle of Eusebius and Greek Chronographic Tradition. Lewisburg: Bucknell University Press, 1979.

Opitz, R. "Ueber den 'Weiberspiegel' des Semonides von Amorgos." Philologus 50 (1891) 13-30.

Pellizer, Ezio. "La donna del mare: la dikē amorosa 'assente' nel giambo di Semonide sopra le donne, vv. 27-42." QUCC, n.s. 3 (1979) 29-36. 
- "Sulla cronologia, la vita e l'opere di Semonide Amorgino." QUCC, n.s. 14 (1983) 17-28.

Rohde, Erwin. "Ѓ́ $\gamma$ ove in den Biographica des Suidas." RhM 33 (1878) 161-220.

- "Studien zur Chronologie der griechischen Literaturgeschichte." $R h M$ 36 (1881) 380-434, 524-75.

Ruppel, W. "Zur Verfassung und Verwaltung der amorginischen Städte.” Klio 21 (1926-27) 313-39.

Schmid, W., and O. Stählin. Geschichte der griechischen Literatur. Munich: C. H. Beck, 1929.

Schmiel, R. "Youth and Age: Mimnermus 1 and 2." RFIC 102 (1974) 283-89.

Severyns, A. Recherches sur la Chrestomathie de Proclos. Paris: Les Belles Lettres, 1938.

Svenbro, Jesper. La parole et le marbre: aux origines de la poétique grecque. Dissertation, Lund, 1976.

Thivel, Antoine. Cnide et Cos? Essai sur les doctrines médicales dans la Collection hippocratique. Paris: Les Belles Lettres, 1981.

Verdenius, W. J. "Semonides über die Frauen: ein Kommentar zu Fr. 7." Mnemosyne 21 (1968) 132-58.

Vlastos, Gregory. "Equality and Justice in Early Greek Cosmologies." CP 42 (1947) 156-78.

West, Martin L. "Alcmanica." CQ, n.s. 15 (1965) 188-202.

- Iambi et Elegi Graeci. Oxford: Oxford University Press, 1972.

-. Studies in Greek Elegy and Iambus. Berlin: de Gruyter, 1974. 